\title{
Characterisation of opacity factor from group-A streptococci
}

\author{
G. A. SARAVANI and D. R. MARTIN \\ New Zealand Communicable Disease Centre (previous/y National Health Institute), PO Box 50348 , Porirua, \\ New Zealand
}

\begin{abstract}
Summary. Extracellular opacity factor (OF) from group-A Streptococcus M-type 22 was purified by ammonium sulphate precipitation followed by ion-exchange on DE-52 cellulose and gel filtration on sephacryl S-400. OF was eluted near the void volume and shown to be heterogenous by sodium dodecyl sulphate-polyacrylamide gel electrophoresis. Antiserum to ammonium sulphate-purified OF from a cell-free culture supernate was prepared in rabbits. All preparations of OF from supernate and cell-extract were inhibited by the antiserum. No $M$ protein was detected in the OF samples from various purification steps. The purified OF showed activity at a broad $\mathrm{pH}$ range with optimal activity at $\mathrm{pH} 6$; it was inactivated considerably at high temperatures. Enzyme activity was inhibited by pepstatin A, but was unaffected by serine proteinase inhibitor, aprotinin, ethylene diamine trichloroacetic acid, Nethylmaleimide, iodoacetamide and mercaptoethanol. This suggests that $\mathrm{OF}$ is an aspartic proteinase.
\end{abstract}

\section{Introduction}

Several infections are associated with streptococci of Lancefield's group A (Streptococcus pyogenes) two of the most common being pharyngitis and impetigo. Post-streptococcal diseases such as acute glomerulonephritis and rheumatic fever, although less common, are more serious, and are important health problems in New Zealand. ${ }^{1,2}$ The ability of group-A streptococci to cause infection in man is primarily attributed to the $\mathbf{M}$ protein of the cell wall that enables streptococci to resist phagocytosis. Immunity is mediated by antibodies directed against the $M$ proteins. Identification of group-A streptococci based on specific $\mathbf{M}$ protein type is essential in studies of the epidemiology, pathogenesis and therapy of streptococcal infection. Some $\mathbf{M}$ types are poorly immunogenic in animals and antisera against them are difficult to prepare. ${ }^{3,4}$ Most of these serotypes produce opacity factor (OF), an enzyme which produces opacity in serum. The opacity-inhibition test is used as a supplementary typing system for the identification of OF-producing $\mathbf{M}$ types ${ }^{5}$ but $\mathrm{OF}$ antisera, like $\mathrm{M}$ antisera, are difficult to prepare. ${ }^{4,6}$ Therefore, we examined the physicochemical nature of OF as a first step in the development of a better method for antiserum production.

Received 23 Feb. 1990; accepted 14 March 1990.

\section{Materials and methods}

\section{OF-producing strain}

$S$. pyogenes; R68/3116, T12, M22 ${ }^{4}$ was used in these experiments. For OF production, the organism was grown at $37^{\circ} \mathrm{C}$ in Todd-Hewitt broth supplemented with neopeptone $1 \%$ according to the method of Hallas and Widdowson. ${ }^{7}$

\section{$O F$ purification from culture supernate}

The cells from $1 \mathrm{~L}$ of culture were sedimented by centrifugation $(4000 \mathrm{~g}, 30 \mathrm{~min})$. The supernate was filtered through a $0 \cdot 45-\mu \mathrm{m}$ membrane filter to remove residual cells. Protein in the cell-free supernate (CFSOF) was precipitated by adding ammonium sulphate to $60 \%$ saturation at $4{ }^{\circ} \mathrm{C}$. This precipitated protein containing the extracellular OF (ASP-OF) was dialysed against $0.01 \mathrm{M}$ Tris- $\mathrm{HCl}, \mathrm{pH} 7.5$, and then applied to a DE-52 cellulose column $(1.6 \times 40 \mathrm{~cm})$ equilibrated with $0.1 \mathrm{M}$ Tris- $\mathrm{HCl}$, pH 7.5, containing $0 \cdot 1 \mathrm{M} \mathrm{NaCl}$. OF was eluted with a linear salt gradient of $0.1-0.6 \mathrm{M} \mathrm{NaCl}$ in $0.1 \mathrm{M}$ Tris- $\mathrm{HCl}, \mathrm{pH} 7 \cdot 5$. OF fractions were pooled, dialysed against $0.01 \mathrm{M}$ Tris- $\mathrm{HCl}, \mathrm{pH} 7 \cdot 5$, and freeze-dried. The lyophilised enzyme was dissolved in $3 \mathrm{ml}$ of distilled water and applied to a sephacryl S-400 gel filtration column $(2.7 \times 100 \mathrm{~cm})$ equilibrated with $0.1 \mathrm{M}$ Tris- $\mathrm{HCl}$, $\mathrm{pH} 7 \cdot 5$, containing $0.1 \mathrm{M} \mathrm{NaCl}$; 6-ml volumes were collected.

\section{OF purification from cell-extract}

The cells from $1 \mathrm{~L}$ of culture were washed three times 
with saline, deposited by centrifugation, resuspended in $7 \mathrm{ml}$ of saline and sonicated for $8 \mathrm{~min}$ in ice, with a Heat Systems Ultrasonics Model W-375 instrument. Sonicates were then centrifuged at $17000 \mathrm{~g}$ for $1 \mathrm{~h}$. The supernate was purified as described for OF from culture supernate. OF from sedimented cells was also extracted by sodium dodecyl sulphate and sodium deoxycholate methods. ${ }^{4}$

\section{Sodium dodecyl sulphate-polyacrylamide gel electrophoresis (SDS-PAGE)}

Electrophoresis of purified $\mathrm{OF}$ in a polyacrylamide vertical $10 \%$ gel slab was by the method of Laemmli. ${ }^{8}$

\section{$M$ protein detection}

Samples from various stages of purification were tested against the reference $\mathrm{M} 22$ antiserum by the double gel diffusion technique. A reference acid extract of M22 was included as a control.

\section{Protein determination}

Protein concentration was determined by the method of Lowry. ${ }^{9}$

\section{Assay of $O F$ activity}

Opalescence in human or horse serum was assayed by the serum-agarslide ${ }^{5}$ and optical density $(O D)^{10}$ methods. In the OD method, $100 \mu \mathrm{l}$ of horse or human serum was incubated with $10 \mu \mathrm{l}$ of OF sample at $37^{\circ} \mathrm{C}$. This method was used to quantify OF activity. The OF activity unit (OFU) was defined as the opacity absorbance of the reaction mixture at $450 \mathrm{~nm}$ after incubation for $4 \mathrm{~h}$. Specific activity was derived from the quotient of the total OF activity and the protein concentration of the OF sample.

\section{Time-dependent OF activity}

The activity of the OF preparations, CFS-OF and ASP-OF, was compared. OD readings were taken at 30min intervals for $6 \mathrm{~h}$, an extra reading was taken after 15 min for ASP-OF.

\section{Serial dilution of $O F$ samples}

The preparations ASP-OF and CFS-OF were each serially diluted and the activity of a $10-\mu \mathrm{l}$ sample of each dilution was determined after $2 \mathrm{~h}$ and $22 \mathrm{~h}$.

\section{pHoptimum}

The influence of $\mathrm{pH}$ on $\mathrm{OF}$ activity of the purified preparation (PP-OF) $(42 \mu \mathrm{g} / \mathrm{ml})$ was examined by adjust- ing the $\mathrm{pH}$ of horse serum with concentrated $\mathrm{HCl}$ to give a range of $\mathrm{pH}$ values from 4 to 11 .

\section{Heat stability}

Samples of PP-OF $(42 \mu \mathrm{g} / \mathrm{ml})$ in $0.1 \mathrm{M}$ Tris- $\mathrm{HCl}, \mathrm{pH}$ 7.5 , containing $0.1 \mathrm{M} \mathrm{NaCl}$ were incubated at $55^{\circ} \mathrm{C}$ and $95^{\circ} \mathrm{C}$ in Kimax Hungate tubes in a heating block. Samples incubated at $55^{\circ} \mathrm{C}$ were removed at 10 -min intervals and those incubated at $95^{\circ} \mathrm{C}$ at 5 -min intervals; these were immediately chilled in an ice-water bath and the residual $\mathrm{OF}$ activity was compared with that of an unheated sample. OD readings were obtained after $2 \mathrm{~h}$.

\section{The effect of inhibitors, denaturing and reducing agents on $O F$ activity}

PP-OF $(42 \mu \mathrm{g} / \mathrm{ml})$ was incubated for $2 \mathrm{~h}$ at room temperature in given concentrations (table II) of various inhibitors, denaturing agents and reducing agents. The residual $O F$ activity of each sample was determined after incubation with horse serum for $4 \mathrm{~h}$.

\section{The effect of various metals on $O F$ activity}

The PP-OF sample $(42 \mu \mathrm{g} / \mathrm{ml})$ was dialysed against distilled water at $4^{\circ} \mathrm{C}$ and the effect of metals on OF activity was determined as described for inhibitors.

\section{Preparation of antiserum}

The following preparations were used as antigens at concentrations given: (i) ASP-OF $(5 \mathrm{mg} / \mathrm{ml})$; (ii) PP-OF $(0 \cdot 82 \mathrm{mg} / \mathrm{ml})$; (iii) sephacryl S-400 purified OF from cell extract $(1.2 \mathrm{mg} / \mathrm{ml})$. For the initial injection, a $1-\mathrm{ml}$ sample of antigen preparation mixed with Freund's complete adjuvant was injected into a 5-month-old Rex rabbit. ASP-OF was injected intraperitoneally and PPOF and sephacryl-purified OF subcutaneously. After 5 days a course of $1-\mathrm{ml}$ of antigen preparation was given on 3 consecutive days for 2 weeks, intravenously for ASPOF and intraperitoneally for the other two preparations. The serum was tested 5 days after the last injection and if antibody was detected a further $1-\mathrm{ml}$ booster injection was given 5 days before final bleeding. In the absence of antibody, three further injections were given before bleeding. Antibody was detected by both slide $^{5}$ and optical density ${ }^{10}$ methods for the opacity-inhibition test.

\section{Results}

\section{$O F$ purification from cell-free supernate}

A large portion of non-enzyme protein and coloured material was removed during the ammonium-sulphate precipitation and ion-exchange chromatography stages, and $c .58 \%$ of the original $\mathrm{OF}$ activity was lost. When OF was further purified 
by sephacryl S-400 gel-filtration chromatography, the enzyme was eluted near the void volume suggesting $\mathrm{OF}$ aggregation. The $\mathrm{OF}$ obtained from the last stage of purification had a specific activity of $2986 \mathrm{OFU} / \mathrm{mg}$ of protein. The results of enzyme purification are shown in table I.

The purified OF was shown to be heterogeneous by SDS-PAGE; it comprised four major protein bands of $30-65 \mathrm{~K}$ da. No $\mathrm{M}$ protein was detected in the OF samples at the various stages of purification.

\section{Time-dependent $O F$ activity}

With the purified and concentrated OF, maximum serum opacity was obtained within $1 \mathrm{~h}$, whereas with the less concentrated OF, opacity increased over $6 \mathrm{~h}$ (fig. 1).

\section{Serial dilution}

ASP-OF at a dilution of 1 in 256 after incubation for $22 \mathrm{~h}$ produced a serum opacity (OD reading) similar to that given by a dilution of 1 in 2 incubated for only $2 \mathrm{~h}$. Similarly, OF from culture supernate produced opacity at a 1 in 2 dilution in $2 \mathrm{~h}$, similar to that of a 1 in 64 dilution in $22 \mathrm{~h}$ (fig. 2).

\section{pH optimum}

The PP-OF enzyme had a broad $\mathrm{pH}$ profile of activity, the optimum was $c$. pH 6 (fig. 3).

\section{Heat stability}

The PP-OF activity after heating to $55^{\circ} \mathrm{C}$ and $95^{\circ} \mathrm{C}$ is shown in fig. 4 . The enzyme was unstable at high temperatures; c. $90 \%$ of $\mathrm{OF}$ activity was lost after $5 \mathrm{~min}$ at $95^{\circ} \mathrm{C}$ (fig. 4).

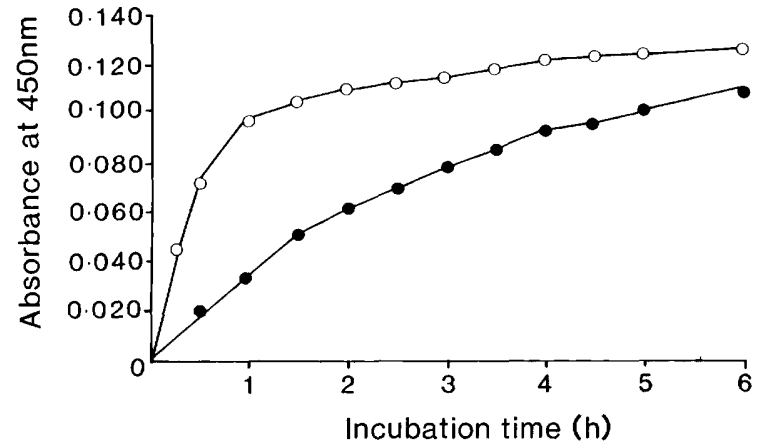

Fig. 1. Time-dependent $O F$ activity. The enzyme activity of $O F$ preparations ASP-OF $(O)$; and CFS-OF $(O)$ compared at 30 min intervals up to $6 \mathrm{~h}$ by OD measurement. (For ASP-OF an extra reading was taken after $15 \mathrm{~min}$ ).

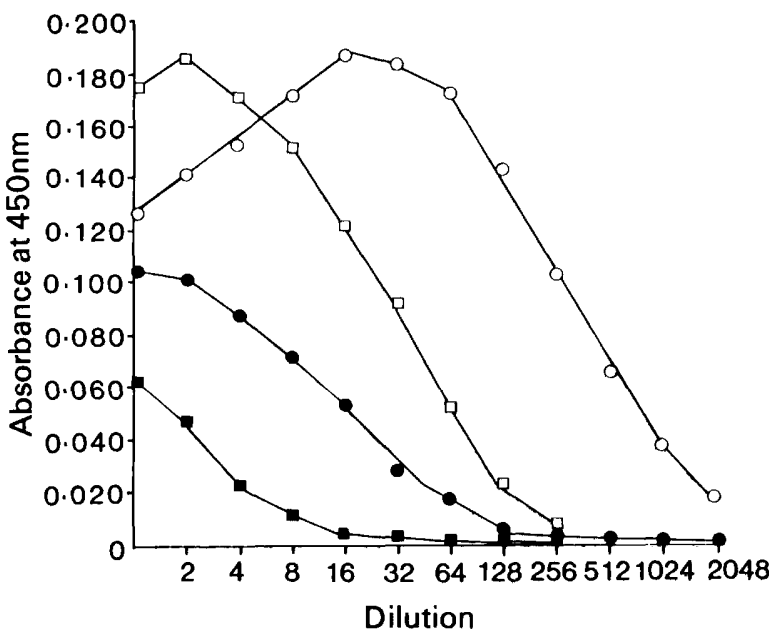

Fig. 2. Serial dilution of OF samples. The enzyme activity of each dilution of $O F$ preparation was measured by OD after incubation for $2 \mathrm{~h}$ and $22 \mathrm{~h} \mathrm{ASP-OF}-2 \mathrm{~h}(0), 22 \mathrm{~h}(\mathrm{O})$; CFS$\mathrm{OF}-2 \mathrm{~h}(\square), 22 \mathrm{~h}(\square)$.

Table I. Purification of OF from M-type-22 Streptococcus, strain R68/3116

\begin{tabular}{lccccc}
\hline \multicolumn{1}{c}{ Sample } & $\begin{array}{c}\text { Volume } \\
(\mathrm{ml})\end{array}$ & $\begin{array}{c}\text { Protein } \\
(\mathrm{mg} / \mathrm{ml})\end{array}$ & $\begin{array}{c}\text { Total } \\
\text { protein } \\
(\mathrm{mg})\end{array}$ & $\begin{array}{c}\text { Total } \\
\text { activity } \\
(\mathrm{OFU})\end{array}$ & $\begin{array}{c}\text { Specific activity } \\
(\mathrm{OFU} / \mathrm{mg} \text { of pro- } \\
\text { tein) }\end{array}$ \\
\hline $\begin{array}{l}\text { Cell-free supernate } \\
\text { (CFS-OF) }\end{array}$ & 1000 & $10 \cdot 4$ & 10400 & 29200 & $2 \cdot 8$ \\
$\begin{array}{l}\text { Ammonium sulphate pre- } \\
\text { cipitate (ASP-OF) }\end{array}$ & 55 & $9 \cdot 6$ & 528 & 16896 & 32 \\
$\begin{array}{l}\text { Cellulose DE 52 purified } \\
\begin{array}{l}\text { Sephacryl S-400 purified } \\
\text { (PP-OF) }\end{array}\end{array}$ & 68 & 0.72 & 48.96 & 12185 & 248 \\
& 60 & 0.042 & 2.52 & 7524 & 2986 \\
\hline
\end{tabular}




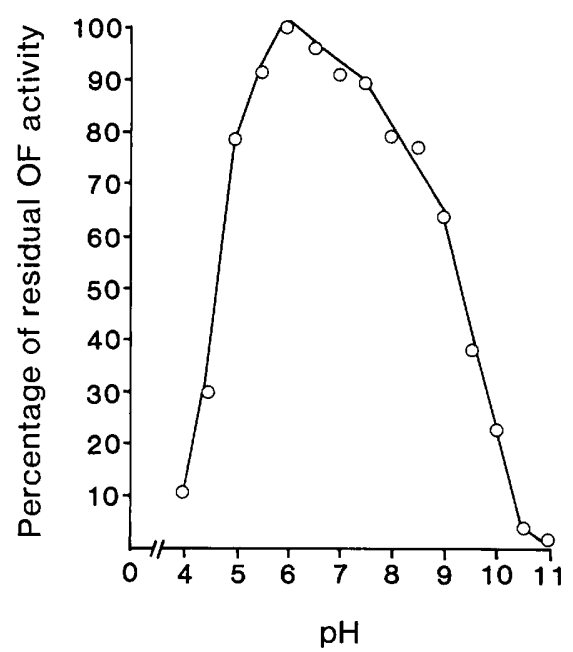

Fig. 3. The effect of $\mathrm{pH}$ on $\mathrm{OF}$ activity in horse serum.

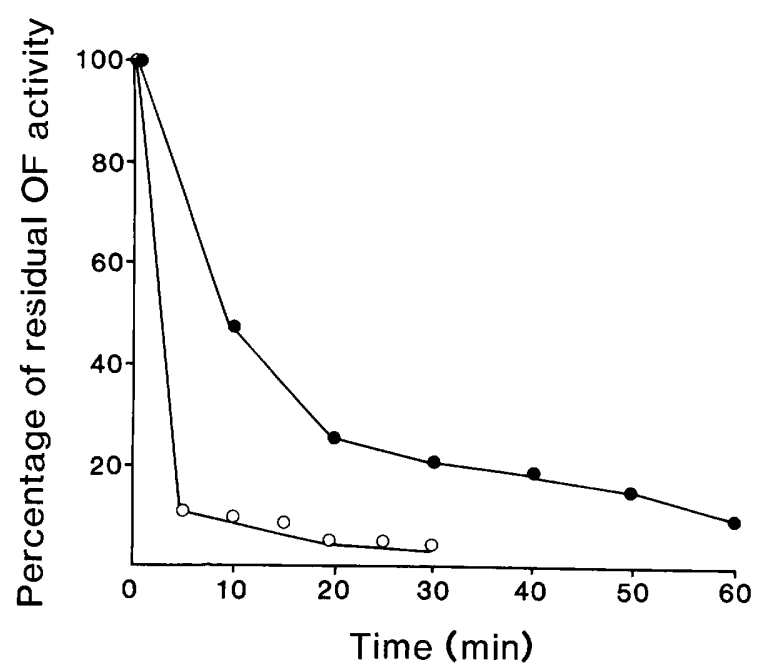

Fig. 4. Determination of heat stability. Purified OF $(42 \mu \mathrm{g} / \mathrm{ml})$ in $0.1 \mathrm{M}$ Tris- $\mathrm{HCl}, \mathrm{pH} 7.5$, containing $0.1 \mathrm{M} \mathrm{NaCl}$ was incubated at $55^{\circ} \mathrm{C}(\bigcirc)$ and $95^{\circ} \mathrm{C}(\mathrm{O})$. Residual OF activity was measured by $\mathrm{OD}$.

\section{The effect of inhibitors, denaturing and reducing agents on $O F$ activity}

PP-OF was inhibited by $5 \mathrm{~mm}$ pepstatin A (aspartic proteinase inhibitor) but was unaffected by PMSF (serine proteinase inhibitor), aprotinin (trypsin, chymotrypsin and plasmin inhibitors), ethylene diamine trichloroacetic acid (EDTA), ophenanthroline (metal chelator), mercaptoethanol and dithiothreitol (reducing agents active against disulphide bonds), iodoacetamide and $\mathrm{N}$-ethylmaleimide (alkylating agents active against free sulphydryl groups). The enzyme was completely inhibited by trypsin and proteinase $\mathrm{K}$ (table II).
Table II. The effect of inhibitors, denaturing and reducing agents on PP-OF activity

\begin{tabular}{lc}
\hline \multicolumn{1}{c}{ Treatment } & $\begin{array}{c}\text { Percentage residual } \\
\text { activity }\end{array}$ \\
\hline Untreated OF (control) & 100 \\
10 mM PMSF & 104 \\
Aprotinin (40 trypsin inhibitor units) & 114 \\
5 mM pepstatin A & 11 \\
1 mM pepstatin A & 93 \\
4 M urea & 25 \\
1\% SDS & 53 \\
25 mM sodium-deoxycholate & 46 \\
10 mM EDTA & 119 \\
10 mM 0 -phenanthroline & 97 \\
\% mercaptoethanol & 100 \\
10 mM dithiothreitol & 110 \\
10 mM iodoacetamide & 107 \\
10 mM N-ethylmaleimide & 97 \\
Trypsin 0.25 mg/ml & 0 \\
Proteinase K $0 \cdot 25$ mg/ml & 0 \\
& \\
\hline
\end{tabular}

\section{The effect of metals on $O F$ activity}

The PP-OF enzyme was sensitive to potassium cyanide and $O F$ activity was reduced in the presence of cupric chloride, mercuric chloride and sodium citrate (table III).

\section{Preparation of antiserum}

Preparation of antisera against the sephacryl S400 purified OF from both culture supernate and cell-extract was not successful, whereas immunising the rabbit with ASP-OF from the supernate of broth culture produced antiserum with a titre of 128. This antiserum specifically inhibited the activity of all OF preparations.

\section{Discussion}

Group-A streptococci can be divided into more than 80 distinct types, determined by the type-

Table III. The effect of various metals on PPOF activity

\begin{tabular}{lc}
\hline \multicolumn{1}{c}{ Treatment } & $\begin{array}{c}\text { Percentage residual } \\
\text { activity }\end{array}$ \\
\hline Untreated OF (control) & 100 \\
$10 \mathrm{mM}$ calcium chloride & 101 \\
$10 \mathrm{mM}$ zinc sulphate & 99 \\
$10 \mathrm{mM}$ magnesium sulphate & 98 \\
$10 \mathrm{mM}$ cupric chloride & 70 \\
$10 \mathrm{mM}$ mercuric chloride & 87 \\
$10 \mathrm{mM}$ sodium citrate & 66 \\
$10 \mathrm{mM}$ potassium phosphate & 106 \\
$10 \mathrm{~mm}$ potassium cyanide & 42 \\
\end{tabular}


specific M-protein antigens and OF. ${ }^{11}$ Although recognition of the $M$ protein of a strain has always been regarded as the definitive test, ${ }^{12,13}$ this requires $M$ antisera of good quality. OF typespecificity parallels the $M$ type, ${ }^{3-5}$ so that when good $M$ antisera are not available the opacityinhibition test has been the method of choice for the identification of OF-producing $M$ types. However, $O F$ antisera, like $M$ antisera, have proved difficult to prepare. Fraser ${ }^{6}$ reported in her studies that only $61(44 \%)$ of 138 rabbits vaccinated produced OF antibodies and at low titres $(<16)$. She attributed these results to inconsistencies in the rabbits' response and described a much higher success rate with guinea-pigs. Attempts in our laboratory, before this study, to produce OF antisera in guinea-pigs by Fraser's method were not particularly successful; only $8(24 \%)$ of 34 guinea-pigs responded $;{ }^{14}$ a heat-killed whole-cell vaccine was used. The current study shows that $75 \%$ of OF activity is inactivated within $20 \mathrm{~min}$ at $55^{\circ} \mathrm{C}$ (fig. 4 ), suggesting that previous failures to stimulate an immune response in guinea-pigs and rabbits may have been due to the inoculation of insufficient quantities of enzyme to serve as antigen.

Failure to evoke an antibody response may also relate to changes produced in the antigen during purification. Our attempts to prepare antiserum against sephacryl S-400-purified OF were unsuccessful. Martinez et al. ${ }^{15}$ similarly failed to obtain OF antibody against OF purified by isoelectric focusing from an M-type-2 streptococcus.

We were able to evoke a specific antibody response in rabbits with highly active preparation of OF. Response to less active OF preparations were poorer.

An important aspect of this study has been the demonstration that OF activity, in common with all enzyme activity, is time-dependent. The same opacity reaction occurs after overnight incubation in serum of very weak OF preparations that occurs

\section{REFERENCES}

1. Talbot RG. Rheumatic fever in the Hamilton health district : a nine year prospective study. $N Z$ Med $J 1988$; 101 : 406-408.

2. Lennon D, Martin D, Wong E, Taylor, LR. Longitudinal study of poststreptococcal disease in Auckland; rheumatic fever, glomerulonephritis, epidemiology and $\mathbf{M}$ typing 1981-86. NZ Med J 1988; 101 : 396-398.

3. Gooder H. Association of a serum opacity reaction with serological type in Streptococcus pyogenes. $J$ Gen Microbiol 1961; 25 : 347-352.

4. Widdowson JP, Maxted WR, Grant DL. The production of opacity in serum by group A streptococci and its within $2 \mathrm{~h}$ with high concentrations of OF. In determining a strain's capacity to produce OF, overnight incubation of the supernate-serum mixture is useful but when testing the OF activity of vaccines as a measure of potency, overnight incubation may give misleading results.

This study has confirmed the findings of other workers that OF activity is inactivated by proteinases $^{7,16}$ and by extremes of $\mathrm{pH}^{16}$ The modification of the substrate at extremes of $\mathrm{pH}$ could have some effect on OF activity, however, OF activity was also reduced by SDS, sodium deoxycholate, and urea.

It has been shown that during purification of $\mathrm{OF}$ by gel filtration, OF forms aggregates which dissociate in the presence of SDS to reveal several protein bands in gel. ${ }^{7,15}$ Similar phenomena were observed in the present study during OF purification.

Previously we showed that OF cleaves the apoprotein Al of serum high-density lipoprotein and the OF was designated as an apoproteinase. ${ }^{17}$ These studies showed that OF activity was in hibited by pepstatin $\mathrm{A}$, an aspartic proteinase inhibitor, but not by serine, metal and sulphydryl proteinase inhibitors, suggesting that $O F$ is an aspartic proteinase. Because mercaptoethanol and dithiothreitol, both reducing agents active against disulphide bonds, had no effect on enzyme activity, we may infer that disulphide bonds do not contribute to OF stability. Urea and SDS detergents, known to dissociate hydrogen and hydrophobic bonds, ${ }^{18}$ disrupted the activity of OF. This finding supports the involvement of hydrophobic interaction and hydrogen bonds in OF stability.

This study is published by the authority of the DirectorGeneral of Health, New Zealand. We thank Mr W. Chisnall, Wellington Hospital, Miss H. Heffernan, New Zealand Communicable Disease Centre, for helpful discussion, and Mrs B. Gordon for typing services. relationship with the presence of $\mathbf{M}$ antigen. $J$ Gen Microbiol 1970; 61 : 343-353.

5. Maxted WR, Widdowson JP, Fraser CAM, Ball LC, Bassett DCJ. The use of the serum opacity reaction in the typing of group A streptococci. J Med Microbiol 1973; 6: $83-90$.

6. Fraser CAM. Preparation of specific antisera to the opacity factors of group A streptococci. J Med Microbiol 1982; 15: $153-162$.

7. Hallas G, Widdowson JP. The opacity factor of group-A streptococci. J Med Microbiol 1982; 15: 451-464.

8. Laemmli UK. Cleavage of structural proteins during the assembly of the head of bacteriophage T4. Nature 1970; 227: 680-685. 
9. Lowry OH, Rosebrough NJ, Farr AL, Randall RJ. Protein measurement with the folin phenol reagent. $J$ Biol Chem $1951 ; 193$ : 265-275.

10. Johnson DR, Kaplan EL. Microtechnique for serum opacity factor characterization of group A streptococci adaptable to the use of human sera. J Clin Microbiol 1988; 26: 2025-2030.

11. Fischetti VA. Streptococcal $\mathbf{M}$ protein: molecular design and biological behavior. Clin Microbiol Rev 1989; 2: 285-314.

12. Lancefield RC. Current knowledge of type-specific $\mathbf{M}$ antigens of group A streptococci. J Immunol 1962; 89: 307-313.

13. Fox EN. M proteins of group A streptococci. Bacteriol Rev 1974; 38: 57-86.

14. Meekin GE. The role of the group A streptococcus in acute glomerulonephritis in New Zealand. PhD Thesis, University of Otago, Dunedin, 1982: 49.
15. Martinez OV, Rippe DF, Fuller L, Streitfeld MM. Purification of the extracellular opacity factor of a strain of group A streptococcus M type 2. J Gen Microbiol 1978; 105: 29-38.

16. Hill MJ, Wannamaker $\mathrm{LW}$. The serum opacity reaction of Streptococcus pyogenes: general properties of the streptococcal factor and of the reaction in aged serum. $J$ Hyg (Camb) 1968; 66:37-47.

17. Saravani GA, Martin DR. Opacity factor from group A streptococci is an apoproteinase. FEMS Microbiol Lett $1990 ; 68$ : 35-40.

18. Yonath A, Sielecki A, Moult J, Podjarny A, Traub W. Crystallographic studies of protein denaturation and renaturation. 1. Effect of denaturants on volume and $\mathrm{X}$-ray pattern of cross-linked triclinic lysozome crystals. Biochemistry 1977; 16: 1413-1417. 